\title{
Tourism Marketing in Bangladesh: What, Why and How
}

\author{
Tarafder Md. Mehedi Al- Masud
}

Lecturer, School of Business Studies, Southeast University, Dhaka, BANGLADESH

\begin{abstract}
Bangladesh is a fresh tourism destination. She has a vast prospective to develop tourism primarily because of its attractive unadulterated natural beauty, heroic historical background and archeological resources, which can be experienced all throughout the land. Tourism sector can play positive impact towards enhancing Gross Domestic Product (GDP).Many countries are now dependent on this sector for foreign currency earnings. Every destination country is trying to achieve more gain by developing this industry. The expansion of the tourism throughout the world has increased. Countries are trying to attract more tourists by adopting appropriate marketing techniques and strategies. A research revealed that the country has a positive trend in arrivals and earnings, and it can be increased to a significant level if the country can undertake appropriate promotion measures by increasing the allocation for this purpose. The country also needs to employ creative people for this purpose, and the quality of the promotional materials also needs to be developed. The paper has been undertaken to investigate how the use of promotional activities can help to develop the tourism industry by giving a special concentration in the case of Bangladesh by observing the current scenario, opportunity, and challenges. The study has intended to evaluate the effective $\mathcal{E}$ sustainable tourism marketing for this country.
\end{abstract}

Keywords: Tourism, GDP, Foreign Currency, Budget, Opportunities, Challenges, Marketing Plans \& Promotions

\section{INTRODUCTION}

In modern world, tourism is measured as one of the world's foremost developing industry. As the tourism is capable of having a significant influence on economic development it can add extra value to the Bangladeshi economy. While most of the neighboring countries in South Asia and South East Asia have already been successfully operating their tourism industry, in Bangladesh, the infra-structural arrangement for services is developing, as well as the role of government in developing tourism aspects is becoming extensively positive, along with private and public organizations having come forward side by side to attract the local and foreign tourists; Bangladesh has a bright prospect for its tourism industry. In Bangladesh, tourism will ensure to earn more revenue than presently if resources are efficiently used via target oriented market positioning.

BPC has come up with a study, which once again confirmed immense prospect of country's tourism. The study Called 'Bangladesh Tourism Vision 2020' forecast those tourist arrivals to Bangladesh likely to exceed 1.30 million by 2020 .

If recommended actions are taken, WTO Tourism 2020 vision study forecasts average annual growth Rate of 6.10 per cent between 1995 and 2020 for south Asia and BPC's Bangladesh forecasts at least 500,000 visitor arrivals by 2020. According to recent trend in arrivals, the BPC study indicates average annual growth rate in tourist arrivals to Bangladesh would be much above the WTO estimates. "It is fairly realistic to forecast that total arrivals to Bangladesh would reach about 900,000 in 2020. Even, the number of tourists may exceed 1.30 million provided that the favorable market situation prevails."

In the face of stiff competition among the destination countries, effective promotional measures are essential for the development of the industry. Days ago Bangladesh Parjatan Corporation or Bangladesh's tourism could not meet this requirement due to lack of needed fund along with the absence of decision-makers' foresightedness. As a result, this sector and its market have failed to grow properly not merely because it lacks enough attractions and facilities. But time has not yet past over. Still there are lots of scopes and opportunities if Bangladesh attempts to highlight it as a tourist destination to the potential tourists properly through an effective promotional measure and can take some initiatives to develop some infrastructural facilities, the country would be able to earn many times higher than the present by attracting more tourists within a short time. That means the aim of tourism marketing is ensure a positive experience for local people; tourism related companies or organization; and tourists themselves. So an integrated approach to tourism planning, development and management is required for a notable sustainable growth of tourism sector that will be able to meet the needs of the present tourists without compromising the future tourists in Bangladesh. 


\section{OBJECTIVES OF THE STUDY}

The overall objective of this study is to find out the potentiality of tourism marketing to develop Bangladesh's tourism sector. The specific objectives of this study are:

- To identify the importance of tourism marketing in Bangladesh.

- To assess the current scenario of tourism marketing in Bangladesh.

- To explore future prospects of tourism marketing in Bangladesh.

- To suggest some recommendations for development of tourism sector.

\section{LITERATURE REVIEW}

According to Crippen dort "Tourism marketing is to be understood as the systematic and coordinated execution of business policy by tourist undertakings whether private or state-owned at local, regional, national or international level to achieve the optimal satisfaction of the needs of identifiable consumer groups, and in doing so to achieve an appropriate return."

Deegan and Moloney (2007) observed for Ireland west the strong correlation of the tourist succor to economic growth and employment. In the context of overall macroeconomic activity there is good reason to believe that tourism can be a signification contributor to economic development in the years ahead if an appropriate emphasis and strategy is developed.

Researchers noticed that developing countries are deprived of benefits derived from tourism and suggested proper planning that includes the socio-cultural, economic and environmental factors Bulter (1974); Edelmann (1975); Huma\&wall (1979) and Sadler \& Archer (1974). Subsequently, tourism practitioners and international organizations started working with tourism and began to use it is an effective tool for poverty alleviation. Etsuko Okazaki (2008) showed that community participation in the tourism planning process is advocated as a way of implanting sustainable tourism. This paper reviewed the principal used it discuss community including the ladder of citizen participation, power distribution, collaboration processes and social capital for motion.

Afjal et al. (2005) identified foreign tourists' attitude toward service product arrangement, channel of distribution, price of tourism product and services and promotional arrangement. He also showed marketing constraints that affect the attitude of the foreign tourists. $\mathrm{He}$ recommends that Bangladesh tourism industry should arrange its marketing mix elements in a way that attain positive attitudes of the foreign tourists and ensure growth of the country.

Shahabuddin (1986) described tourism industry in Bangladesh has not got a solid footing to "taken off" despite all the efforts and measures from government and other private agencies.
Kale and Wire (1986) states people have country specific attracting and repelling factors which affect tourists' choice and decision regarding their travel to a country. So, promotion of tourism of a country is greatly depended on the magnitude of publicity.

There are a number of tourist facilities in Bangladesh. But in some cases information of these are not available to the tourists. Bangladesh Parjatan Corporation (BPC) should change its marketing strategy with an aim to building up a good image of Bangladesh (Hasan, 1992).To support tourism in the country Biman has failed to understand that the customers real want, satisfaction and other requirements (Kamal and Chowdhury, 1993). The major problems of tourism in Bangladesh are over population, natural disasters, unemployment, and economic underdevelopment (Hall and Page, 2000). In this regard, we like to explore different aspect of tourism marketing in Bangladesh through this study.

\section{JUSTIFICATION OF THE STUDY}

Bangladesh is one of the most beautiful and historical place of the world. It has the potential to explore its tourism sector. Even it can easily attract a large number of local and foreign tourists for its unique features and earn a large amount of foreign exchanges through tourism marketing. Marketing has been acknowledged as the most imperative management activity in the tourism industry which is rising at a different rapid rate. It is especially important because of the perishable and intangible nature of the tourism product. Since customers vary in their requirements, marketers need to identify their market, study their needs, develop a product and create a marketing mix to meet the demands of the selected market segment or target market. This paper intends to identify the tourist products of Bangladesh, why it is needed and how it can be done. In that sense, this article would be crucial questions and answers for our policy makers.

\section{METHODOLOGY OF THE STUDY}

Necessary information and data were collected from secondary sources. While in this process different books, journals, magazines and periodicals have been reviewed. In addition to these, a lot of tourism related websites has been reviewed for updated information. On the other hand, several foreign and local research works has been reviewed in this field.

\section{LIMITATION OF THE STUDY}

The findings of this study can be generalized after considering certain limitations. The study is mainly based on secondary data. Moreover, enough literature was not available to relay the area of study regarding Bangladesh perspective. 


\section{TOURISM MARKETING: ANALYSIS \& FINDINGS}

The marketing experts opine that, tourism marketing is the systemic and coordinated efforts to optimize the satisfaction of tourism. The tourism marketing is also supposed to be a device to make a possible reorientation in the business policy and overhaul in the management concept. Tourism marketing is an integrated effort to satisfy tourists by making the best possible services available to them. It is an approach to promote business, which feeds the organizations the necessary information for farming or revamping the marketing decisions. The tourisms marketing is thus promotion or sales based on research on what are to be sold in the market.

Tourism marketing has distinct characteristics from other marketing plans. Because tourists are temporary, they are exposed to an area's goods and services for shorter periods. But tourists are counting on having a good time, so marketers should consider strategies that appeal to the emotions, such as treating kids to a memorable experience. Tourism-dependent businesses rely on other organizations. Tourism marketing involves several steps. Market research seeks to understand the consumer, while product development aims to meet his needs. Analysis and selection of target markets, also known as segmentation, means studying potential customer groups and selecting only certain groups whose needs and wants can be best met with a certain producer's product. Marketing strategy seeks to reach the target markets using promotion, advertising, pricing and distribution.

Marketing communications occur in three ways: external, internal and word-of-mouth. External marketing uses formal communication channels to promote the tourism product to the traveler, boasting of its benefits and making promises. Internal marketing communication occurs when the tourism service provider makes contact with the tourist and delivers the promised benefits. Word-of-mouth communication occurs informally when visitors or employees discuss their experiences of the tourism product to others.

There are different purposes of tour by the intended people. Bangladesh Parjatan Corporation classified the causes of tourism as tourism, business, office, study, religion, service and other purpose Literature study reveals other types of tourism which are termed as medical tourism, slum tourism, and halal tourism etc.

\section{Site Tourism}

Among many reasons, visiting natural sites to enjoy scenic beauty is one of the major reasons for tourism. Huge natural attractions constitute this country as a paradise for the tourists both from home and abroad.

\section{Business Tourism}

The second highest number of people from across the world visit Bangladesh for business purpose. Based on our natural resources galore, strategic geographic location, distinct competitive edge and comparative, industries have huge prospects to grow in Bangladesh to cater to the vast domestic market as well as to capitalize the privileged market access being enjoyed by Bangladesh from developed countries through export (Chowdhury S.)

\section{Office Tourism}

There are so many global, international and multinational companies doing business in Bangladesh. Of these, mentionable are A. K. Khan \& Co. Ltd, Avery Dennison Bangladesh Ltd., Berger Paints Bangladesh Limited, Bureau Veritas Consumer Products Services (Bangladesh) Ltd., Novartis (Bangladesh) Limited and aamra, a collection of 14 companies, involved in the Textiles and Apparels, Information \& Communication Technologies and Lifestyle Service sector in Bangladesh over the last 22 years mentionable (www.bangladeshtrades.com)

\section{Education Tourism}

Williams P., (Jan 2010) stated that Educational tourism is tourist activity undertaken by those who are an overnight vacation and those who are undertaking an excursion for whom education and learning is a primary or secondary part of their trip. Universities arrange many international seminars, conferences, and symposiums and attract academicians and students seeking knowledge across the world.

\section{Religious Tourism}

Bangladesh is the world's third-largest Muslim-majority nation. She arranges so many religious programs like Bishwa Ijtema and other religious gatherings. She attracts Muslim around the world. Moreover, there are a few people of Hinduism, Christianity and Buddhism come to Bangladesh for religious interests.

\section{Medical Tourism}

Medical science could be a good source of medical tourism. Recently some of the international standard hospitals are established in Bangladesh. These can make new horizon for medical tourism. Though the medical tourism in Bangladesh is not well recognized, it may create a huge opportunity in near future. The other wing of medical tourism is online medical which is large online database providing necessary information to attract people to come to the country in person.

\section{Other Tourism}

Other forms of Tourism includes Bicycle Touring, Boat Sharing, Cultural Tourism, Dark Tourism, Rural Tourism, River Cruise, Nautical Tourism, Jihadi Tourism, Halal Tourism, Sports Tourism, Slum Tourism, Virtual Tour, Walking Tour, Wildlife and Water Tourism. Very often, people come for a Short Visit, Meet Relatives, Participating Sports and International Awareness Programs, etc.

\section{TOURISM Products OF BANGLADESH}

Bangladesh has the potential to be a prime host of tourist destination as it has lots of tourists' attractions. The total scenario of tourism products/attractions can be discussed under the following broad categories of products: 


\section{Eco-Tourism products}

Bangladesh is a country filled with natural wonders and untouched reserves and home to a variety of unique and magnificent creatures. With hills, valleys, forests, beaches, lakes and rivers, ecotourism in Bangladesh is ideal. The Sundarbans is the world's largest mangrove forest and could be the goldmine for ecotourism in Bangladesh. The UNESCO has already declared Sundarbans as a worldheritage site with a view to preserving and protecting biodiversity of the rare ecotourism.

Cox's Bazar is the tourist capital of Bangladesh with a $120 \mathrm{~km}$ long sandy, straight and drivable beach. Other special attractions of Cox's Bazar are Inani beach, the island of Maheskhali (famous for its Buddhist and Hindu temples and a dry fish industry), Teknaf (the southernmost point of Bangladesh), Ramu, Sonadia, Himchhari, St. Martin Island (only Coral Island) etc.

The three Hilly Districts of Rangamati, Khagrachari and Bandarban are inhabited by a number of tribes, with their distinctive cultures, rituals, and traditions. Chimbuk, Ruma, Rain-Khyoung valleys, keocradang and Tazinsdang are highly attractive products in the hill tracts.

Sylhet, the most tea granary of the country, is another eco attraction of the country.

Kuakata beach, where both sun rise and sunset are seen, is another tourist landmark of the country.

So, Bangladesh has rich and varied flora and fauna-a biological phenomenon, which simply describes as unique in the Bangladesh.

\section{Archeological Tourism products}

Bangladesh is a country considerably rich in archeological wealth, especially of the medieval period both during the Muslim and pre-Muslim rules though most of it is still unexplored and unknown. The earlier history of Bangladesh reveals that Buddhism received royal patronage from some great ruling dynasties like the great Pala rulers the Chandra and the Deva Kings. Under their royal patronage, numerous well-organized, self-contained monasteries sprang up all over the country. The major archeological sites are

Paharpur (the most important and the largest known monastery south of the Himalayas has been excavated).

Mahasthangor (Several isolated mounds, the local names of which are Govinda Bhita Temple, Khodai Pathar Mound, Mankalir Kunda, Parasuramer Bedi, Jiyat Kunda, etc. surround the fortified city).

Mainamati (An isolated low, dimpled range of hills dotted with more than 50 ancient Buddhist settlements of the 8th to 12 th century AD known as Mainamati-Lalmai range are extended through the center of the district of Comilla).

Shait-Gumbad Mosque (most imposing and largest multidomed mosques in Bangladesh, known as the Shait-Gumbad Masjid).

Kantanagar Temple (The most ornate among the late medieval temple of Bangladesh is the Kantanagar temple near Dinajpur town which was built in 1752 by Maharaja Pran Nath of Dinajpur)

\section{Historical Tourism Products}

Historical monuments of Bangladesh represent Hindu, Muslim, British periods and independent scattered all over the country. Major historical attractions are:

Lalbagh Fort (Aurangabad Fort, commonly known as Lalbagh Fort that indeed represents the unfulfilled dream of a Mughal Prince).

Sonargaon (Sonargaon is one of the oldest capitals of Bengal. It was the seat of Deva Dynasty until the 13th century. From then onward till the advent of the Mughals, Sonargaon was subsidiary capital of the Sultanate of Bengal).

World War II Cemetery (In this well-preserved cemetery, in Chittagong lie buried over 700 soldiers from Commonwealth countries and Japan, who died during the Second World War).

Gandhi Ashram (This ashram was established in the memory of the historic visit of the Mahatma Gandhi to Noakhali and devoted to his ideology).

Mujibnagar Memorial (The beautiful memorial dedicated to the first provisional revolutionary government of Bangladesh that was declared here on 14 April 1971 during the liberation war).

National Memorial (the national memorial was designed by architect Moinul Hossain. It was dedicated to the sacred memory of the millions of unknown martyrs' of the war of liberation in 1971).

Central Shahid Minar (Symbol of Bengali nationalism, this monument was built to commemorate the martyrs' of the historic language movement on 21st February, 1952).

Martyred Intellectual Memorial (the memorial was built to commemorate the intellectuals who were killed in 1971 by the Pakistan's occupation forces just two days ahead of the Victory Day).

National Poet's Grave (Revolutionary poet Kazi Nazrul Islam died on 29th August 1976 and was buried here. The graveyard is adjacent to the Dhaka University Central Mosque).

Old High Court Building (It was originally built as the residence of the British Governor; the High Court Building illustrates a good blend of European and Mughal architecture).

\section{Religious Tourism Products}

Key religious tourism products are:

The Shrine of Hazrat Shah Jalal (The great Muslim Saint, Hazrat Shah Jalal (R.A.) is said to have brought the message of Islam to the region in the early 14 th century. His shrine is located at Dargah Mahalla in the heart of Sylhet town). Mosque (Dhaka has several hundred historic mosques. Prominent are the Seven Domed Mosque (17th century), BaitulMukarram - National Mosque, Star Mosque (18th century), Chawkbazar Mosque and Huseni Dalan Mosque). 
Bayazid Bostami Majar (This holy place in Chittagong attracts a large number of visitors and pilgrims. At its base there is a large pond with several hundred huge tortoises and fishes floating on the water).

Kantaji Temple (The most ornate among the late medieval Hindu temples of Bangladesh.) Every inch of the temple surface is beautifully embellished with exquisite terracotta plaques, representing flora and fauna, geometric motifs, mythological scenes and an astonishing array of contemporary social, and favorite pastime).

\section{Cultural Tourism Products}

Sonargaon (Sonargaon dating back to 13th century is one of the oldest capitals of Bengal. A folk -art and craft museum has been established here. Among the ancient monuments still intact are the tomb of Sultan Abdul Alla and a beautiful mosque in Goaldi village).

Natore - Dighapatiya Rajbari (The palace has large, spacious grounds and is surrounded by a great moat. The palace has well-equipped guest-house, an imposing gateway and a nice garden decorated with statues of white marble). Shilaidaha Kuthibari (The beautiful mansion carries memory of Nobel laureate poet Rabindranath Tagore who made frequent visit to this place and used to stay here, in connection with administration of his Zamindari and enriched Bengali literature through his writings during that time).

Sagordari (The birth place of the celebrated poet Micheal Madhusudan Dutta by most accounts the first modern poet of Bangla Literature). Trishal (It is the place where innumerable boyhood memories of our national poet Kazi Nazrul Islam are found around). Shahjadpur Kuthibari (It is also a historical place connected with the frequent visits of poet RabindranathTagore).

Ahsan Manzil Museum (On the bank of river Buriganga in Dhaka the Pink majestic Ahsan Manzil has been renovated and turned into a museum recently. It is an epitome of the nation's rich cultural heritage. It is the home of Nawab of Dhaka and a silent spectator to many events. Todays renovated Ahsan Manzil a monument of immense historical beauty).

\section{Recreational Tourism Products}

Bangladesh has world's largest unbroken sea beach, thousands of rivers and rivulets, numerous lakes and cannels which provide recreation facility like seed boat, paddle boat, simple boat, swimming, squash, etc. to the tourist such as angling, boating, swimming, fishing, etc. We also have rich classical dances, arts, and music, etc. that may attract both foreign and local tourists.

\section{Adventure tourism Products}

The Sundarban and Hill District in Chittagong offer unique and challenging opportunity for adventure tourists. They can gather thrilling experience seeing Royal Bengal Tiger, Spotted Deer, Barking Deer,
Crocodiles, Other reptiles and highest peaks on the northern side of Bangladesh.

\section{IMPORTANCE OF TOURISM MARKETING: BANGLADESH PERSPECTIVE}

Marketing generates awareness about Bangladesh's position as a tourist destination in the established markets at regional and international levels.

Once a consumer has heard of a particular state or site of Bangladesh, then need to convince him he wants to go there. Marketing taps into what they want.

Destination images are heavily influenced by pictorial creations used in televisions or satellite channels, by music and in some cases by popular entertainer or celebrities.

Marketing helps to target new and potential markets by identifying and monitoring changing designs and needs for various market types such as China, Japan, East European and South America, and South Asian countries.

To enhance Bangladesh's competitive position in the intercontinental destination market by mobilizing effective promotional measures supported by attractive proposals and appealing tourism products.

\section{MARKETING OF TOURISM PRODUCTS IN BANGLADESH: THE WAY OUT}

Advertising is the best way for initial publicity of tourist attractions. There are many different advertising methods that organizations can choose according to their needs and demands. These methods are print media, broadcasting media, and online. These kinds of marketing tools are used highly in this modern age. These are also some effective ways of international marketing. These marketing methods do not have any border limit. Sometimes these are the cheapest way of marketing goods and services. Again customers can get all information like price, facilities, opening time, contract information, and recent activities of the company and its history very effectively through those links. Customers could mail to the service provider for any information if they needed. (Sweeney 2008, 3-10.) Branding should be applied in tourism or destination marketing because everything depends on branding. If people can make or create strong brand image about a tourist attraction, then it will be popular in the world overnight. Branding is like a life blood for any product or destination (Keller 2011,25-26.)

Nowadays, the Internet has become a part of our life. People spend a big portion of their time everyday using the internet, chatting with friends and acquaintances and always want to be connected with them by different social media like Facebook, YouTube, blogs and so on. Again the number of internet users is increasing day by day. Hence, for tourism marketing, social media can be good tools. We can already see that most of the tourism organizations have their videos or online advertisement 
in YouTube, similarly they have different pages on Facebook to connect people and give up-to-date information about their services. The concept of social media marketing means optimizing the site in which the written content garners links which act as trust endorsement in the purpose of listening to what the community often does and responses. It helps to boost up the brand awareness and raise the visibility of product or services for the targeted customers. In addition, social media is defined as a process that empowers individuals to promote their websites, products or services through online social channels and to communicate with and tap into a much larger community that may not have been available via traditional advertising channels. (Scott 2010, 77-79.)

Advertise on travel websites another important. The number of blogs, online magazines, and information websites about travel is endless; capitalize on existing readership with simple banner advertisements. Choose travel websites that target audience is likely to read, and pay for ads that appear "above the fold," on the top of the page where they can be seen without scrolling. Design advertisements that are simple, compelling and easy-to-read.

Have to write guest posts on travel blogs or have to start a travel column in a print publication. Choose topics that are relevant to tourism offerings are necessary so that they will attract people who have an interest in locations or types of trips. Have to understand needs and preferences of customers. Work with shifts in the economy and market to refine marketing message are beneficial.

Bangladesh will benefit from this initiative if it installs some international standard tourist facilities among the attractive areas. Among these are the establishment of exclusive tourist zones, construction of 5-star hotels, installation of golf-course, establishment of sea sports, etc. Installation of traditional apparel shopping malls of Bangladesh at tourist place is another way to grab tourism market. It is widely known that the traditional shopping malls of Bangladesh are attracting shoppers from regional and European countries because of cheap price as well as subtle weaving and knitting of apparels.

Implement of business tourism will create vital impact on Bangladesh tourism sector. Business tourism is providing services and facilities to the millions of delegates or individuals who annually attend conventions, meetings, exhibitions, congresses, business events, incentive travel and corporate hospitality. It is concerned with people traveling for purposes related to their work. There is a huge potential to promote business tourism in some major divisional and district towns of Bangladesh such as Chittagong, Cox's Bazar, Rajshahi and Khulna. Also, by developing business tourism we can help develop many backward linkage sectors in the country. Besides, this will create many informal jobs like tea vendors, food corners, betel shops, hawkers, etc.

\section{TOURISM MARKETING IN BANGLADESH: THE CONSTRAINTS}

Although Bangladesh has potential to flourish a very expected tourist destination, but the following problems are crucial for the development for implementing the marketing plan for tourism in Bangladesh:

- Lack of financial support from government.

- Low rate of illiterate people/ inadequate education system.

- Absence of training institute related to tourism.

- Lack of efficient infrastructure facilities.

- Lack of market information.

- Lack of contact with the market.

- Lack of appropriate tourism policy.

- Lack of Safety \& Security.

\section{RECOMMENDATIONS}

Develop the management education in tourism marketing and prepare marketing or sales people to promote the product properly to the right place in regional and global perspectives.

Effective and predicative working network should be introduced between public and private sector is a must. Local people should involve with them.

Tourist information center can be introduced across the country for the tourist where they can get information about their expected destination, Transportation and residing place and other necessary information.

Tribal shopping center should be established at every tourist place to make handicraft available to both domestic and foreigner tourist.

Bangladesh Tourism Corporation should open a research center for the foreigners for further research in tourism.

Good governance that is related to government interaction and dealing with business by means of regulatory affairs is rather a big problem for the sustainable tourism development in Bangladesh. The rules and regulations, enacted with the benign view of facilitating and helping tourism, rather acts as a regulatory and problem creating mechanism.

In starting new tourism business, most simple and one stop permission procedure can encourage private entrepreneurs to invest in this sector. Entrepreneurs must not have to take permissions from a number of different ministries and departments.

Bangladesh has huge tribal population living mostly in the Chittagong Hill Tracts and in the regions of Mymensingh, Sylhet, and Rajshahi. The majority of the tribal population lives in rural areas, where many practiced shifting cultivation. They have fully different culture and life style. Many curious tourists interested in their culture and life style may be attracted by promoting tribal tourism.

Bangladesh is a giant of the Muslim world. Anything termed as halal (anything abides by Sharia) creates extra appeal to the Muslim. Halal tourism is a new product 
Asian Business Review, Volume 5, Number 1/2015 (Issue 10) ISSN 2304-2613 (Print); ISSN 2305-8730 (Online)

in the tourism industry that provides holiday destinations for Muslim families who abide by Sharia rules. The hotels in such destinations do not serve alcohol and have separate swimming pools and spa facilities for men and women. The Halal tourism will also provide flights where no alcohol or pork products are served, prayer timings are announced, and religious programs are broadcast as part of entertainment offered board.

To deliver information to the foreign tourist through online, or website and information technology is necessary to research about new tourist spots.

Training and other updated courses should be conducted at regular intervals to update the personnel with efficiency.

Security is another important aspect of the development of the tourism industry. For ensuring safety and security of tourists, a new wing of Bangladesh Police has started to serve. Political stability is also one of the strong preconditions to attract tourists. Infrastructure should be developed with a target-oriented planning, which must be properly implemented.

\section{CONCLUSION}

Tourism is the emerging industry in the world. Bangladesh has more potential to attract foreign tourists, as well as boost up internally. But this potential can be converted into a reality through dynamic marketing of the tourism products and services. Survival and growth of the tourism industry will depend to a large extent marketing approach. Countries are competing with each other to market their destinations. So as soon as possible effective marketing plan should be implement for the success of Bangladesh tourism.

\section{REFERENCE}

Afroz Nahida \& Md. Hasanuzzaman "Problems \& prospects of tourism in Bangladesh Bandarban district case", Global journal of management and business research,vol.3, issue. 23, version 1.0, 2012

Ahmed Shahabuddin. (1986). "Tourism in Bangladesh" -, Bangladesh Quarterly, Vol.6,

Andrews, S.2007, Introduction to Tourism and Hospitality Industry, Tata McGraw-Hill Co LTD, New Delhi

Awan, A. (2015). Shifting Global Economic Paradigm. Asian Business Review, 4(3), 35-40. Retrieved from http://journals.abc.us.org/index.php/abr/article/view/Ghafoor

Bhatia, A.K.2001, International Tourism Management, Sterling Publishers Pvt Ltd., New Delhi

Biman Bangladesh Airlines" Journal of Business Studies, Dhaka University.Vol. 14(1), pp 47-67.

BPC, 2007, "Bangladesh tourism vision 2020" Morshed M.M.R (edited), Dhaka Bangladesh published by the Bangladesh Parjatan Corporation, Dhaka, Bangladesh.

Butler, R.W (1974). "The social implications of tourist development". Annals of Tourism Research, Vol. 16, No. 3, pp.377-398.

Chowdhury, T., \& Chowdhury, M. (2015). An Analysis of Guest Occupancy and Profit of Private and Public Hotels in Cox's Bazar. Asian Business Review, 4(3), 50-59. Retrieved from http://journals.abc.us.org/index.php/abr/article/view/Chowdhury
Deegan, Jim and Molony, Richard. (2007). “Understanding the economic contribution of tourism to economic development: The case of Ireland west." Global Business and Economics Anthology, Volume 2, December.

Dey, P., Uddin, S., \& Hasan, M. (2015). Tourists' Perception towards Cox's Bazar Sea Beach in Bangladesh as a Tourist Destination. Asian Business Review, 2(1), 54-60. Retrieved from http://journals.abc.us.org/index.php/abr/article/view/Dey

Edelmann, K.M.S (1975). "Major problems of tourism growth in developing countries." Annals of Tourism Research, vol.3, no 1 , pp. 33-42.

Ghosh, B.2000, Tourism and Travel Management, Vikas Publishing House Ltd., New Delhi

Hall C. M. \& S. Page. (2000). “Tourism in South and Southeast Asia: Issues and Cases"-, London, Butterworth Heinemann, p.218.

Haque Ziaul, 2012, “Tourism in Bangladesh: Problems and prospects", New Age, January

Haque Ziaul, 2013, "Implementing innovative ideas for attracting tourists,"The financial express, July

Hasan S.R. (1992). "Problems and Prospects of Tourism Industry in Bangladesh"-, Bureau of Business Research, University of Dhaka, pp 14-15.

Hossain Afjal.(2001). "Marketing Strategies for the Tourism Industry in Bangladesh,"

http://www.tourismboard.gov.bd/

https://www.facebook.com/BangladeshTourismCorporation

Hyman, B., and wall. G. (1979). "Tourism in a developing area: The case of Tamil Nadu, India." Annals of Tourism Research vol. 6, no. 3, pp. 338-350.

Islam, K. (2015). Foreign Direct Investment (FDI) in Bangladesh: Prospects and Challenges and Its Impact on Economy. Asian Business Review, 4(1), 24-36. Retrieved from http://journals.abc.us.org/index.php/abr/article/view/Islam

M.M. Kamal \& A.I.Chowdhury. (1993). "Marketing Orientation in Tourism Sectors: Case Study of Biman Bangladesh Airlines" Journal of Business Studies, Dhaka University.Vol. 14(1), pp 47-67.

Rahman Jahangir, 2013, "Promoting tourism: positive action needed", The Financial Express, October

Rahman, M., \& Ahsan, M. (2015). Foreign Direct Investment as an Instrument for promoting Economic Development in Bangladesh. Asian Business Review, 3(4), 100-107. Retrieved from http://journals.abc.us.org/index.php/abr/article/view /6 .5Rahman

Sadler, P.G. and Archer, B>H> (1974). "The economic impact of tourism in developing countries. Annals of Tourism Research vol. 3, no. 1, pp. 15-32.

Shamsher, R., \& Abdullah, M. (2015). Traffic Congestion in Bangladesh- Causes and Solutions: A study of Chittagong Metropolitan City. Asian Business Review, 2(1), 13-18. Retrieved

from http://journals.abc.us.org/index.php/abr/article/view/Shamsher

Siddique, M., Akhter, M., \& Masum, A. (2015). Service Quality of Five Star Hotels in Bangladesh: An Empirical Assessment. Asian Business Review, 2(2), 67-72. Retrieved from http://journals.abc.us.org/index.php/abr/article/view/4.11Siddique

Sudhir H. Kale \& Katherine M. Weir. (1986)."Marketing Third World Countries to the Western" February

Tinne, W. (2015). Nation Branding: Beautiful Bangladesh. Asian Business Review, 2(1), 31-36. Retrieved from http://journals.abc.us.org/index.php/abr/article/view/Tinne

$$
--0 \text {-- }
$$

